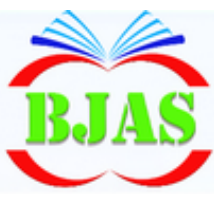

Available online at http://bajas.edu.iq https://doi.org/10.37077/25200860.2019.268 College of Agriculture, University of Basrah

Basrah Journal of Agricultural Sciences

ISSN $1814-5868$

Basrah J. Agric. Sci., 32 (Spec. Issue 2): 193-206, 2019

E-ISSN: 2520-0860

\title{
Activity and Thermodynamic Parameters of Urease Enzymes in Soils Treated with Some Heavy Metals Under Different Temperatures and Moisture Levels
}

\author{
Ali L. Tfaij*, Abdul Mehdi S. Al-Ansari \& Meiad M. Al- Jaberi \\ Department of Soil Sciences and Water Resources, College of Agriculture, University of Basrah, \\ Iraq. \\ *Corresponding author e-mail: $\underline{\text { ali.lt } 8985 @ \text { yahoo.com }}$ \\ Received 19 September 2019; Accepted 18 November 2019; Available online 22 November 2019
}

\begin{abstract}
Incubation studies were conducted to reveal effected heavy metals $(\mathrm{Cd}, \mathrm{Cr}$, $\mathrm{Cu}, \mathrm{Fe}, \mathrm{Mn}, \mathrm{Ni}, \mathrm{Pb}$ and $\mathrm{Zn}$ ) add at critical concentrations to soils with different texture on urease activity and thermodynamic parameters $\left(\mathrm{Ea}\right.$ and $\left.\mathrm{Q}_{10}\right)$ incubated under different temperatures $(10,20,30,40,50,60$ and 70$){ }^{\circ} \mathrm{C}$ for 14 days under field capacity and waterlogged moisture levels. Urease activity was measured and thermodynamic parameters were calculated. Results showed that the urease activity increased with increasing temperature of incubation from 10 to $50^{\circ} \mathrm{C}$ then the activity decreased as temperature increased above $50^{\circ} \mathrm{C}$ at both moisture levels and at all heavy metals treatments. Increasing moisture level from field capacity to water-logged significantly $(\mathrm{P}=0.05)$ decreased urease activity, while increased $\mathrm{Ea}$ value, at all heavy metals treatments. The soil texture significantly affected urease activity and thermodynamic parameters (Ea and $\left.\mathrm{Q}_{10}\right)$. Results also indicated that effect of heavy metals on urease and thermodynamic parameters differed according to the soil temperature and the moisture level.
\end{abstract}

Key words: Urease, Ea, $\mathrm{Q}_{10}$, Heavy metals, Moisture levels soil.

\section{Introduction}

Determination of enzyme activity is essential to determine the biological activity of the soil. Soil enzymes stimulate the biochemical processes of the decomposition of organic matter in soils (Hang et al., 2013). Source of urease enzyme in the soil is living and dead microorganisms such as bacteria, fungi, algae, invertebrates, plant residues, and plant roots and it can be found in soil in as of external enzymes like most soil enzymes (Follmer, 2008). Urease stimulates the hydrolysis of urea to ammonia and carbon dioxide with high efficiency about $10^{14}$ times higher than non-enzymatic reaction (Maroney \& Ciurli, 2013; Cordero et al., 2019).

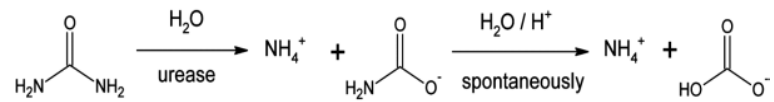

Oliveira \& Pampulha (2006) showed that the activity of urease enzyme in the soil is influenced by several factors, including organic matter content, soil depth, soil management, soil $\mathrm{pH}$ values, the concentration of subject matter, soil moisture, temperature, and heavy metals. 
Contamination of heavy metals seriously adversely affects the natural environment, including reduce enzyme activity in the soil, and the activity of urease enzyme is negatively associated with heavy metals in the soil (Meng et al., 2018). Krajewska (2009) reported that heavy metals inhibit urease activity by forming bonds with sulfhydryl groups in the active site of the enzyme and have taken the following sequence in inhibiting urease activity: $\mathrm{Ag}^{+}=\mathrm{Hg}^{2+}>\mathrm{Cu}^{2+}$ $>\mathrm{Ni}^{2+}>\mathrm{Cd}^{2+}>\mathrm{Zn}^{2+}>\mathrm{Co}^{2+}>\mathrm{Fe}^{3+}>\mathrm{Pb}^{2+}>$ $\mathrm{Mn}^{2+}$. Enzymatic activity decreases immediately after the introduction of heavy metals into the soil and over time the activity returns to its original level (Ciarkowska \& Gambus' 2004). Soil enzymatic activity is a sensitive indicator of natural and human changes in the ecosystem, which is used to assess the impact of various pollutants including heavy metals in the soil in a long and/or short period time (Ciarkowska et al., 2014). Yang et al. (2006) reported that the activity of urease enzyme increases with increasing temperature. Kumari \& Rao (2017) reported that the activity of urease enzyme increased by increasing the temperature from 20 to $70^{\circ} \mathrm{C}$ and then decreased dramatically as the temperature increased to $90^{\circ} \mathrm{C}$. Machuca et al. (2015) and Al-Ansari (2000) stated that Urease activity increases with increasing temperature from 10 to $50^{\circ} \mathrm{C}$. Fraser et al. (2013) explained as well the significant correlation between urease activity and temperature with activation energy (Ea) of $73.4 \mathrm{kJmol}^{-1}$. Al-Jabri (2010) found that increasing the temperature from 10 to $60{ }^{\circ} \mathrm{C}$ increased urease activity in seven soils with different properties, and $\mathrm{Q}_{10}$ value decreased as temperature increased. Al-Ansari et al.
(2019) also reported that $\mathrm{Q}_{10}$ of urease enzymes increased as temperature increased. Dick \& Tabatabai (1999) noted that the optimal water content of enzyme activity in soils is at the field capacity. Zhang et al. (2016) revealed that Water-logging reduced soil enzyme activity and soil microbial biomass. Gu et al. (2019) reported that the urease activity in a soil in immersed for 3, 6 or 9days decreased as compared to that of the aerated soil. Moreover, the results indicated as immersing period increased, the negative effect on the urease activity increased. Little information is available on the effect of soil temperature and moisture on the role of heavy metals in the activity and thermodynamic parameters of the urease enzymes in the soil of the southern region of Iraq, hence this study was conducted.

\section{Materials \& Methods}

Soil samples from three locations differ in their agricultural status located at southern part of Iraqi, Basrah province (table1) were collected from depth of 0-30 cm. These soils were silty clay classified (fine silty, mixed, active, calcareous, hyperthermic, typic torrifluven), silty clay loam classified (fine clayey, mixed, active, calcareous, hyperthermic, typic torrifluven) and loamy sand classified (sandy, mixed, active, calcareous, hyperthermic, typic torripasmments). Collected samples were kept in a refrigerator $\left(4^{\circ} \mathrm{C}\right)$ for urease enzymes measure. Sub-samples were air dried, grounded and passed through $2 \mathrm{~mm}$ sieve. Some physical and chemical properties of the soil were determined following standard procedures described by page et al. (1982) and presented in table (1). 
Tfaij et al ./ Basrah J. Agric. Sci., 32 (Spec. Issue 2): 193-206, 2019

Table (1): Some chemical, physical and biological properties of studied soils.

\begin{tabular}{llll}
\hline Soil & Silty clay & Silty clay loam & Loamy Sand \\
\hline $\mathrm{pH}$ & 7.83 & 7.59 & 7.82 \\
\hline $\mathrm{ECe}(\mathrm{dS} \mathrm{m}$ & -1 & 8.67 & 4.96 \\
\hline Organic C $\left(\mathrm{gm} \mathrm{kg}^{-1}\right)$ & 11.86 & 1.93 & 1.50 \\
\hline Organic matter $\left(\mathrm{gm} \mathrm{kg}^{-1}\right)$ & 2.04 & 3.28 & 2.55 \\
\hline $\mathrm{CaCO}\left(\mathrm{gm} \mathrm{kg}^{-1}\right)$ & 3.46 & 342 & 279 \\
\hline Total N $\left(\mathrm{gm} \mathrm{kg}^{-1}\right)$ & 396 & 3.64 & 1.21 \\
\hline $\begin{array}{l}\text { Urease activity } \\
\mu \mathrm{g} \mathrm{N}-\mathrm{NH}_{4}^{+} \mathrm{gm}^{-1} \text { soil } 2 \mathrm{hrs}^{-1}\end{array}$ & 4.22 & 80.5 & 56 \\
\hline
\end{tabular}

$100 \mathrm{~g}$ (on air dry bases) of each soil was placed in containers and treated with critical concentration of $\mathrm{Cr}, \mathrm{Cd}, \mathrm{Pb}, \mathrm{Mn}, \mathrm{Cu}, \mathrm{Fe}, \mathrm{Zn}$ and Ni (table 2) (Kabata-Pendias \& Pendias, 2001).

Table (2): The critical concentrations of heavy metals in ppm added to the soil according to (Kabata-Pendias \& Pendias, 2001).

\begin{tabular}{ll}
\hline Element & Critical concentration \\
\hline $\mathrm{Cd}$ & 3 \\
\hline $\mathrm{Cr}$ & 100 \\
\hline $\mathrm{Cu}$ & 100 \\
\hline $\mathrm{Fe}$ & 200 \\
\hline $\mathrm{Mn}$ & 100 \\
\hline $\mathrm{Ni}$ & 50 \\
\hline $\mathrm{Pb}$ & 100 \\
\hline $\mathrm{Zn}$ & 300 \\
\hline
\end{tabular}

Untreated soils were used as control, the soil moisture of all treatments were adjusted to either field capacity (F.C.) or water-logged using distilled water. Samples were incubated at $30^{\circ} \mathrm{C}$ for 14 days, then urease activity was determined. Desired moisture levels of incubated samples were maintained by periodic weighting of the containers. Urease activity of samples was determined following procedure of Tabatabai \& Bremner (1972). Five grams of amended and control soils were incubated with $9 \mathrm{ml}$ of $0.05 \mathrm{M} \mathrm{pH} 9$ tris (THAM) buffer, $0.2 \mathrm{ml}$ of toluene, and $1 \mathrm{ml}$ of $0.2 \mathrm{M}$ substrate (urea) solution at $37^{\circ} \mathrm{C}$ for 2 hours. After incubation, urea was inhibited by addition of $\mathrm{KCl}-\mathrm{Ag}_{2} \mathrm{SO}_{4}$ solution, then $\mathrm{NH}^{4+}-\mathrm{N}$ released was determined by distillation procedure. Thermodynamic parameters were calculated from the results obtained at $0.6 \mathrm{M}$ urea. The activation energy (Ea) of urease in soils was calculated from enzymes activity obtained at $0.6 M$ urea but temperatures of incubation varied from $10^{\circ} \mathrm{C}$ to $60^{\circ} \mathrm{C}$. Ea values were calculated using Arrhenius equation plot of $\log \mathrm{K}$ against $1 / \mathrm{T}$ (Tabatabai, 1994).

$\mathrm{K}=\mathrm{A} \cdot \exp (-\mathrm{Ea} / \mathrm{RT})$

Where A: pre exponential factors, Ea: energy of activity, R: gas constant, $\mathrm{T}$ : temperature (kelvin degree).

$\log K=(-E a / 2.303 R T)+\log A$ 
The temperature coefficient (Q10) was calculated by the formula of Frankenberger \& Tabatabai (1983).

$$
\mathrm{Q} 10=\exp \frac{10000 \mathrm{Ea}}{8.314 \mathrm{~T}(\mathrm{~T}+10)}
$$

The study was carried as factorial experiments with three replicates in complete randomized design. Data were analyzed by two-way analysis of variance (ANOVA) using GenStat program. Least significance difference (LSD) calculated for treatments means at $5 \%$ probability.

\section{Results}

\section{Temperature effects on urease enzyme} activity

Fig. (1) demonstrated increase in urease enzyme. activity by increasing the incubation temperature from 10 to $50^{\circ} \mathrm{C}$, but increasing incubation temperature more than $50^{\circ} \mathrm{C}$ resulted in a significant decrease in the enzyme activity in all studied soils, at both moisture levels and all studied heavy metals. Fig. (1) also

illustrated that increasing moisture levels from field capacity to waterlogging conditions decreased urease activity in soils treated with different elements and incubated at different temperatures. Urease activity in silty clay was higher than the silty clay loam soil and sandy soil which showed lower urease activity under all treatments. Urease activity in control soils were higher than the activity in soils treated with heavy metals under both moisture levels (fig1). The negative effect of heavy metals on urease activity was in order of Zinc $>$ Cadmium $>$ Iron > Lead > Chromium > Copper > Manganese > Nickel under field capacity conditions, however under waterlogged condition the effect follows the order Zinc > Iron > Cadmium $>$ Manganese $>$ Lead $>$ Copper > Chromium $>$ Nickel.. 
Tfaij et al ./ Basrah J. Agric. Sci., 32 (Spec. Issue 2): 193-206, 2019
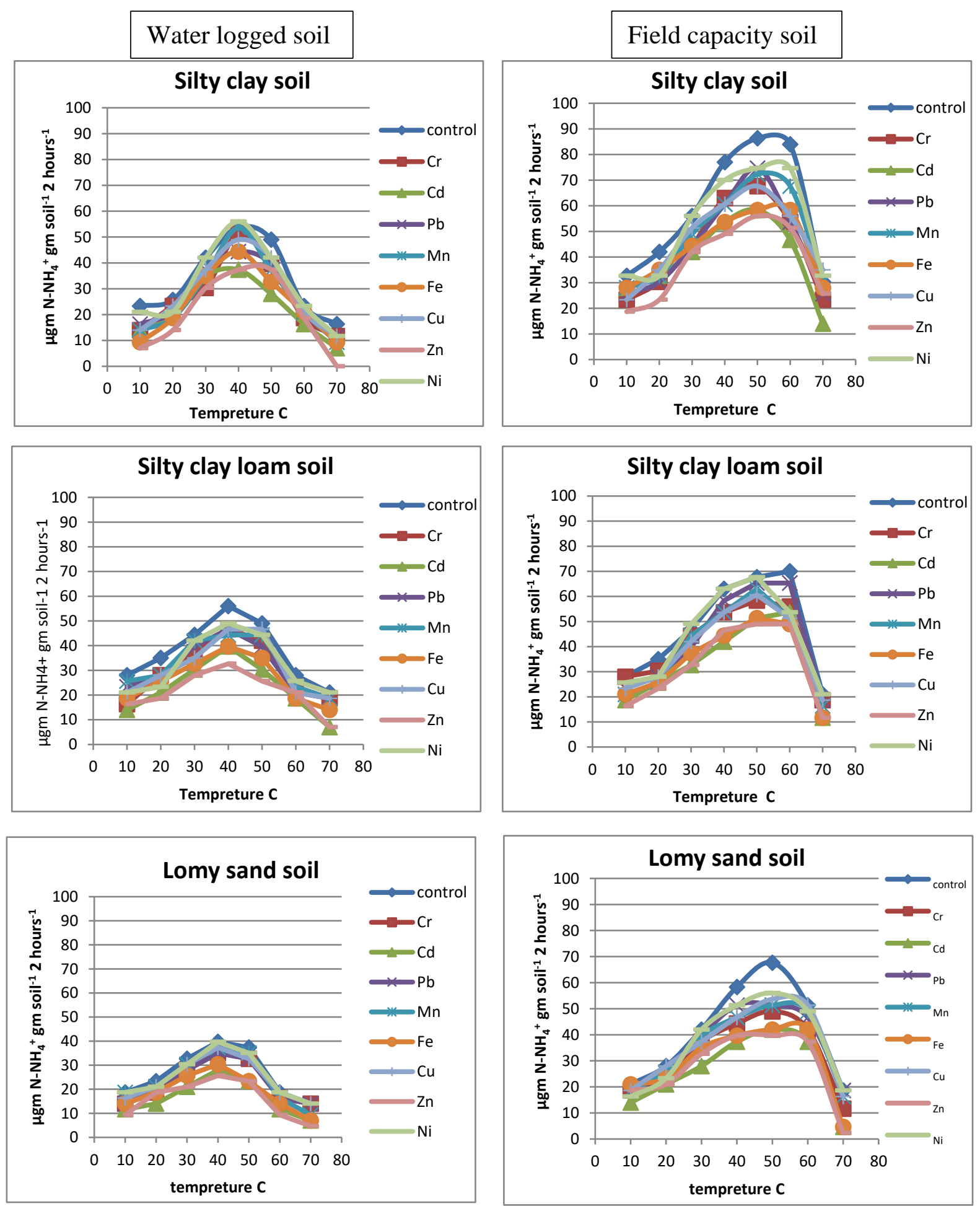

Fig. (1): Effect of temperature $\left({ }^{\circ} \mathrm{C}\right)$ on urease activity of studied soils treated with heavy metals at two moisture levels. 
Tfaij et al ./ Basrah J. Agric. Sci., 32 (Spec. Issue 2): 193-206, 2019

Thermodynamic of urease enzymes: activation energy (Ea) and temperature coefficient $\left(Q_{10}\right)$

Fig. (2) showed a linear relationship between the logarithm of the ammonium amount resulting from the activity of urease enzyme and temperatures of $10-60{ }^{\circ} \mathrm{C}$ in all studied soils treated with different heavy metals and incubated at field capacity and water logged conditions and for all heavy metals. The Ea values of urease in the studied soils were calculated from the negative slope of the straight line (Tables $3 \& 4$ ).

Table (4) indicated that there is a significant difference in the values of $\mathrm{Ea}$ urease enzymes in all studied soils. Ea values ranged from $10.39 \mathrm{~kJ} \mathrm{~mol}^{-1}$ in silty clay soil treated with $\mathrm{Cd}$ to $19.07 \mathrm{~kJ} \mathrm{~mol}^{-1}$ in loamy sand soil treated with $\mathrm{Ni}$ under soil field capacity conditions and $11.36 \mathrm{~kJ} \mathrm{~mol}^{-1}$ in silty clay loam soil treated with $\mathrm{Zn}$ to $33.36 \mathrm{~kJ}$ $\mathrm{mol}^{-1}$ in silty clay soil treated with $\mathrm{Zn}$ under soil waterlogging conditions.

The data of table (4) revealed that $\mathrm{Ea}$ of urease enzymes (as average) in silty clay loam soil did not differ significantly from that of loamy sand soil, but both were higher than Ea value of silty clay soil when soils incubated under field capacity moisture level. However, when soil samples incubated under water logged conditions, Ea values were in order of silty clay > Loamy sand > silty clay loam.

Table (4) demonstrated that effect of heavy metals (as average) on Ea values was in order of: Nickel > Lead > Zinc > Manganese > Copper > Cadmium > Chromium > Iron. under field capacity conditions, but under waterlogged conditions the order was: Zinc > Chromium > Copper $>$ Cadmium $>$ Iron > Nickel > Manganese > Lead. The data of Table (5) displayed that the values of $\mathrm{Q}_{10}$ of urease enzymes ranged from 1.122 in silty clay loam treated with $\mathrm{Zn}$ at $20^{\circ} \mathrm{C}$ to $1.622 \mathrm{in}$ silty clay soil treated with $\mathrm{Zn}$ at $10^{\circ} \mathrm{C}$ under field capacity conditions and from 1.111 in silty clay soil treated with $\mathrm{Cr}$ at $10^{\circ} \mathrm{C}$ to 1.319 in loamy sand soil treated with $\mathrm{Ni}$ under soil waterlogging conditions incubated at $10^{\circ} \mathrm{C}$. Data of table5 indicated that $\mathrm{Q}_{10}$ values (as average) were in order: silty clay soil > Loamy sand soil $=$ silty clay loam soil. Under field capacity condition. However, no significant differences were recorded among Q10 (as average) of soils under study. 
Tfaij et al ./ Basrah J. Agric. Sci., 32 (Spec. Issue 2): 193-206, 2019
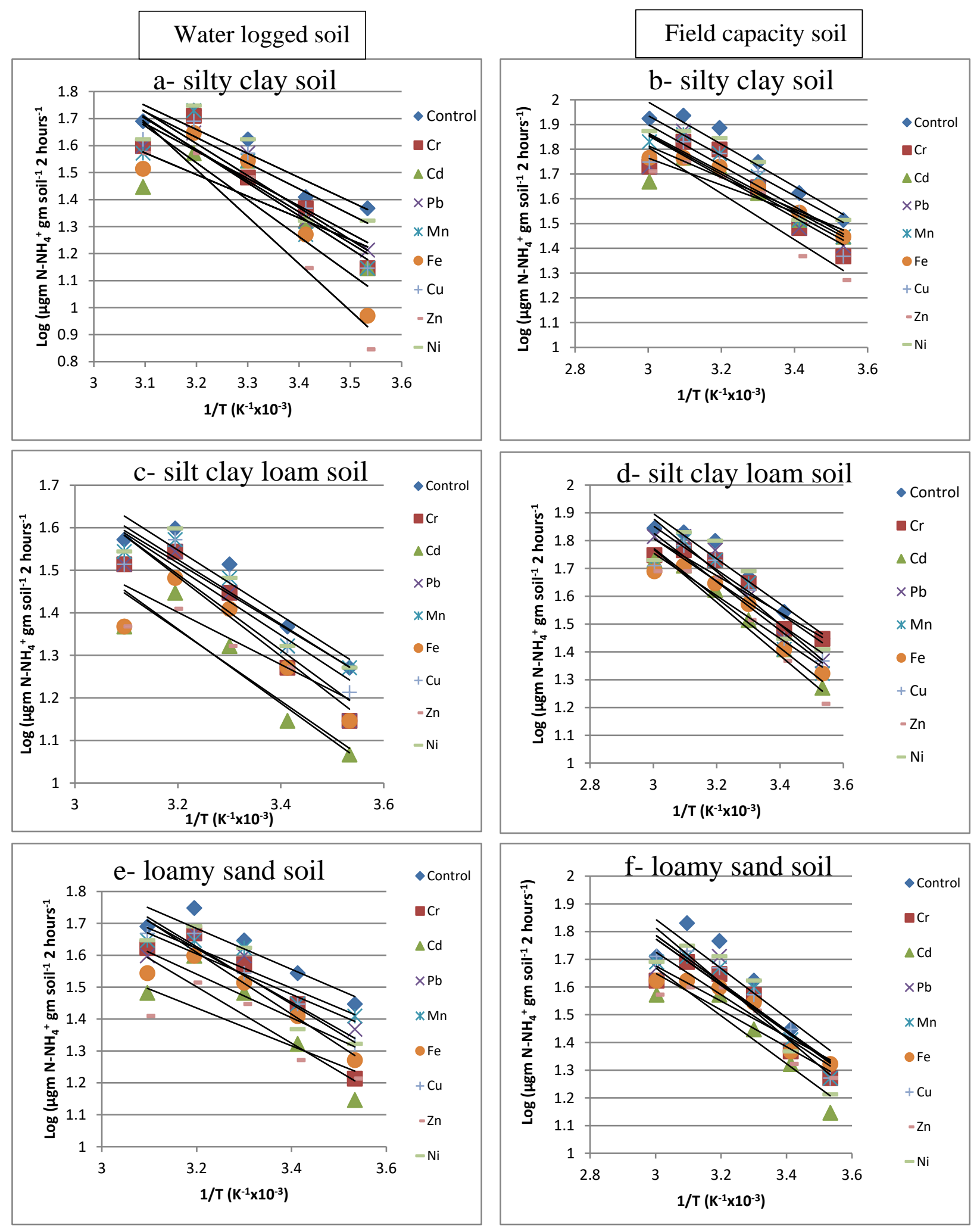

Fig. (2): The linear relationship between $1 / \mathrm{T}$ and $\log \mathrm{NH}_{4}{ }^{+}$released of urease activity of studied soils treated with heavy metals on two moisture levels. 
Tfaij et al ./ Basrah J. Agric. Sci., 32 (Spec. Issue 2): 193-206, 2019

Table (3): Straight-line equation and coefficient of determination (r) for relationship between temperature and urease activity by $\left(\mu \mathrm{g} \mathrm{N}-\mathrm{NH}_{4}{ }^{+} \mathrm{gm} \mathrm{soil}^{-1} 2\right.$ hor $\left.^{-1}\right)$.

\begin{tabular}{|c|c|c|c|c|c|c|}
\hline \multicolumn{7}{|c|}{ Field capacity soil } \\
\hline \multirow{2}{*}{ Treatments } & \multicolumn{2}{|c|}{ silty clay soil } & \multicolumn{2}{|c|}{ silty clay loam soil } & \multicolumn{2}{|c|}{ loamy sand soil } \\
\hline & Equation & $\mathrm{r}$ & Equation & $\mathrm{r}$ & Equation & $\mathrm{r}$ \\
\hline Control & $\begin{array}{l}y=-0.8517 x+ \\
4.5459\end{array}$ & 0.968 & $\begin{array}{l}y=-0.8103 x+ \\
4.3281\end{array}$ & 0.973 & $\begin{array}{l}y=-0.8887 x \\
+4.511\end{array}$ & 0.899 \\
\hline $\mathrm{Cr}$ & $\begin{array}{l}y=-0.8271 x+ \\
4.3363\end{array}$ & 0.894 & $\begin{array}{l}y=-0.6651 x+ \\
3.8028\end{array}$ & 0.944 & $\begin{array}{l}y=-0.7705 x \\
+4.038\end{array}$ & 0.904 \\
\hline $\mathrm{Cd}$ & $\begin{array}{l}y=-0.5428 x+ \\
3.3927\end{array}$ & 0.870 & $\begin{array}{l}y=-0.8968 x+ \\
4.4637\end{array}$ & 0.989 & $\begin{array}{l}y=-0.866 x+ \\
4.2674\end{array}$ & 0.936 \\
\hline $\mathrm{Pb}$ & $\begin{array}{l}y=-0.7987 x+ \\
4.2551\end{array}$ & 0887 & $\begin{array}{l}y=-0.9524 x+ \\
4.7368\end{array}$ & 0.969 & $\begin{array}{l}y=-0.8273 x \\
+4.2559\end{array}$ & 0.904 \\
\hline $\mathrm{Mn}$ & $\begin{array}{l}y=-0.8289 x+ \\
4.3869\end{array}$ & 0.960 & $\begin{array}{l}y=-0.8768 x+ \\
4.4585\end{array}$ & 0.906 & $\begin{array}{l}y=-0.8416 x \\
+4.2991\end{array}$ & 0.936 \\
\hline $\mathrm{Fe}$ & $\begin{array}{l}y=-0.6387 x+ \\
3.73\end{array}$ & 0.969 & $\begin{array}{l}y=-0.7686 x+ \\
4.0616\end{array}$ & 0.959 & $\begin{array}{l}y=-0.635 x+ \\
3.5814\end{array}$ & 0.939 \\
\hline $\mathrm{Cu}$ & $\begin{array}{l}y=-0.7824 x+ \\
4.2121\end{array}$ & 0.886 & $\begin{array}{l}y=-0.7744 x+ \\
4.1322\end{array}$ & 0.919 & $\begin{array}{l}y=-0.8593 x \\
+4.3651\end{array}$ & 0.955 \\
\hline $\mathrm{Zn}$ & $\begin{array}{l}y=-0.9325 x+ \\
4.6055\end{array}$ & 0.928 & $\begin{array}{l}y=-0.9581 x+ \\
4.6444\end{array}$ & 0.957 & $\begin{array}{l}y=-0.6636 x \\
+3.6407\end{array}$ & 0.903 \\
\hline $\mathrm{Ni}$ & $\begin{array}{l}y=-0.8079 x+ \\
4.359\end{array}$ & 0.933 & $\begin{array}{l}y=-0.7869 x+ \\
4.2137\end{array}$ & 0.868 & $\begin{array}{l}y=-0.996 x+ \\
4.8025\end{array}$ & 0.895 \\
\hline \multicolumn{7}{|c|}{ Water logged soil } \\
\hline \multirow{2}{*}{ Treatments } & \multicolumn{2}{|l|}{ silty clay soil } & \multicolumn{2}{|c|}{ silty clay loam soil } & \multicolumn{2}{|l|}{ loamy sand soil } \\
\hline & Equation & $\mathrm{r}$ & Equation & $\mathrm{r}$ & Equation & $\mathrm{r}$ \\
\hline Control & $\begin{array}{l}y=-0.8889 x+ \\
4.504\end{array}$ & 0.930 & $\begin{array}{l}y=-0.6395 x+ \\
3.7306\end{array}$ & 0.921 & $\begin{array}{l}y=-0.7694 x \\
+4.0097\end{array}$ & 0.948 \\
\hline $\mathrm{Cr}$ & $\begin{array}{l}y=-1.1553 x+ \\
5.2822\end{array}$ & 0.918 & $\begin{array}{l}y=-0.9695 x+ \\
4.7117\end{array}$ & 0.916 & $\begin{array}{l}y=-0.933 x+ \\
4.4704\end{array}$ & 0.948 \\
\hline $\mathrm{Cd}$ & $\begin{array}{l}y=-0.8018 \mathrm{x}+ \\
4.0585\end{array}$ & 0.791 & $\begin{array}{l}y=-0.8843 x+ \\
4.331\end{array}$ & 0.872 & $\begin{array}{l}y=-0.8355 x \\
+4.0336\end{array}$ & 0.912 \\
\hline $\mathrm{Pb}$ & $\begin{array}{l}y=-1.0147 x+ \\
4.8267\end{array}$ & 0.918 & $\begin{array}{l}y=-0.6348 x+ \\
3.6357\end{array}$ & 0.884 & $\begin{array}{l}y=-0.8879 x \\
+4.3317\end{array}$ & 0.942 \\
\hline $\mathrm{Mn}$ & $\begin{array}{l}y=-1.216 x+ \\
5.4747\end{array}$ & 0.884 & $\begin{array}{l}y=-0.6225 x+ \\
3.6136\end{array}$ & 0.924 & $\begin{array}{l}y=-0.7335 x \\
+3.8643\end{array}$ & 0.942 \\
\hline $\mathrm{Fe}$ & $\begin{array}{l}y=-1.3679 x+ \\
5.9137\end{array}$ & 0.870 & $\begin{array}{l}y=-0.6834 x+ \\
3.7279\end{array}$ & 0.912 & $\begin{array}{l}y=-0.614 x+ \\
3.366\end{array}$ & 0.814 \\
\hline $\mathrm{Cu}$ & $\begin{array}{l}y=-1.1856 x+ \\
5.4014\end{array}$ & 0.923 & $\begin{array}{l}y=-0.8426 x+ \\
4.3173\end{array}$ & 0.977 & $\begin{array}{l}y=-0.79 x+ \\
4.0337\end{array}$ & 0.920 \\
\hline $\mathrm{Zn}$ & $\begin{array}{l}y=-1.7424 x+ \\
7.0865\end{array}$ & 0.942 & $\begin{array}{l}y=-0.5933 x+ \\
3.3333\end{array}$ & 0.819 & $\begin{array}{l}\mathrm{y}=-0.8729 x \\
+4.1553\end{array}$ & 0.865 \\
\hline $\mathrm{Ni}$ & $\begin{array}{l}y=-0.9511 x+ \\
4.6736\end{array}$ & 0.845 & $\begin{array}{l}y=-0.8977 x+ \\
4.4993\end{array}$ & 0.906 & $\begin{array}{l}y=-0.7583 x \\
+3.9515\end{array}$ & 0.927 \\
\hline
\end{tabular}


Tfaij et al ./ Basrah J. Agric. Sci., 32 (Spec. Issue 2): 193-206, 2019

Table (4): Ea values $\left(\mathrm{KJ} \mathrm{mal}^{-1}\right)$ of urease in studied soils treated with heavy metals on two moisture levels.

\begin{tabular}{ccccccccc}
\hline \multicolumn{7}{c}{ Ea values $\left(\mathrm{KJ} \mathrm{mal}^{-1}\right)$} \\
$\begin{array}{c}\text { Treatmen } \\
\mathrm{t} .\end{array}$ & $\begin{array}{c}\text { Silty } \\
\text { clay soil }\end{array}$ & $\begin{array}{c}\text { Loamy } \\
\text { clay soil }\end{array}$ & $\begin{array}{c}\text { Loamy } \\
\text { sand soil }\end{array}$ & $\begin{array}{c}\text { Average } \\
\text { Silty clay } \\
\text { soil }\end{array}$ & $\begin{array}{c}\text { Loamy } \\
\text { clay soil }\end{array}$ & $\begin{array}{c}\text { Loamy } \\
\text { sand soil }\end{array}$ & Average \\
\hline $\mathrm{Control}$ & 16.31 & 15.51 & 17.02 & 16.28 & 17.02 & 12.24 & 14.73 & 14.66 \\
\hline $\mathrm{Cr}$ & 15.84 & 12.73 & 14.75 & 14.44 & 22.12 & 18.56 & 17.86 & 19.51 \\
\hline $\mathrm{Cd}$ & 10.39 & 17.17 & 16.58 & 14.71 & 15.35 & 19.93 & 16.00 & 17.09 \\
\hline $\mathrm{Pb}$ & 15.29 & 18.24 & 15.84 & 16.45 & 19.43 & 12.15 & 17.00 & 16.19 \\
\hline $\mathrm{Mn}$ & 15.87 & 16.79 & 16.11 & 16.26 & 23.28 & 11.92 & 14.04 & 16.41 \\
\hline $\mathrm{Fe}$ & 12.23 & 14.72 & 12.16 & 13.04 & 26.19 & 13.09 & 11.76 & 17.01 \\
\hline $\mathrm{Cu}$ & 14.98 & 14.83 & 16.45 & 15.42 & 22.70 & 16.13 & 15.13 & 17.99 \\
\hline $\mathrm{Zn}$ & 17.85 & 18.34 & 12.71 & 16.30 & 33.36 & 11.36 & 16.71 & 20.47 \\
\hline $\mathrm{Ni}$ & 15.47 & 15.07 & 19.07 & 16.54 & 18.21 & 17.19 & 14.52 & 16.64 \\
\hline Average & 14.91 & 15.93 & 15.63 & & 21.96 & 14.73 & 15.31 & \\
& & & & & & & & \\
\hline
\end{tabular}

LSD heavy metals $=0.162$, soil $=0.408$, moisture level $=$ n.s, heavy metals* soil $=0.429$, heavy metals $*$ moisture level $=2.156$, moisture level $*$ soil $=2.642$, heavy metals $*$ soil $*$ moisture level $=2.646$. 
Tfaij et al ./ Basrah J. Agric. Sci., 32 (Spec. Issue 2): 193-206, 2019

Table (5): $Q_{10}$ values of urease in heavy metals contaminated studied soil.

\begin{tabular}{|c|c|c|c|c|c|c|c|c|c|c|c|c|c|c|c|c|c|c|}
\hline \multicolumn{19}{|c|}{$\mathrm{Q}_{10}$ values - Field capacity soil } \\
\hline \multirow{2}{*}{ Treat. } & \multicolumn{6}{|c|}{ Silty clay soil } & \multicolumn{6}{|c|}{ Silty clay Loam soil } & \multicolumn{6}{|c|}{ Loamy sand soil } \\
\hline & 10 & 20 & 30 & 40 & 50 & Aver. & 10 & 20 & 30 & 40 & 50 & Aver. & 10 & 20 & 30 & 40 & 50 & Aver. \\
\hline Contr. & 1.280 & 1.188 & 1.241 & 1.224 & 1.210 & 1.229 & 1.194 & 1.132 & 1.168 & 1.157 & 1.147 & 1.160 & 1.238 & 1.160 & 1.205 & 1.192 & 1.179 & 1.195 \\
\hline $\mathrm{Cr}$ & 1.378 & 1.250 & 1.324 & 1.301 & 1.281 & 1.307 & 1.309 & 1.206 & 1.265 & 1.247 & 1.231 & 1.252 & 1.296 & 1.198 & 1.254 & 1.237 & 1.221 & 1.241 \\
\hline $\mathrm{Cd}$ & 1.249 & 1.168 & 1.215 & 1.200 & 1.187 & 1.204 & 1.278 & 1.187 & 1.240 & 1.223 & 1.209 & 1.227 & 1.261 & 1.175 & 1.225 & 1.210 & 1.196 & 1.213 \\
\hline $\mathrm{Pb}$ & 1.326 & 1.217 & 1.279 & 1.260 & 1.243 & 1.265 & 1.193 & 1.131 & 1.167 & 1.156 & 1.146 & 1.158 & 1.280 & 1.187 & 1.241 & 1.224 & 1.209 & 1.228 \\
\hline $\mathrm{Mn}$ & 1.402 & 1.265 & 1.344 & 1.319 & 1.297 & 1.325 & 1.189 & 1.128 & 1.163 & 1.152 & 1.143 & 1.155 & 1.226 & 1.152 & 1.195 & 1.182 & 1.170 & 1.185 \\
\hline $\mathrm{Fe}$ & 1.462 & 1.303 & 1.394 & 1.366 & 1.340 & 1.373 & 1.209 & 1.141 & 1.181 & 1.168 & 1.158 & 1.171 & 1.186 & 1.126 & 1.161 & 1.150 & 1.141 & 1.153 \\
\hline $\mathrm{Cu}$ & 1.390 & 1.258 & 1.334 & 1.310 & 1.289 & 1.316 & 1.264 & 1.177 & 1.227 & 1.212 & 1.198 & 1.215 & 1.245 & 1.165 & 1.212 & 1.197 & 1.184 & 1.201 \\
\hline $\mathrm{Zn}$ & 1.622 & 1.401 & 1.527 & 1.487 & 1.452 & 1.498 & 1.179 & 1.122 & 1.155 & 1.145 & 1.136 & 1.147 & 1.274 & 1.184 & 1.236 & 1.220 & 1.206 & 1.224 \\
\hline $\mathrm{Ni}$ & 1.302 & 1.202 & 1.260 & 1.242 & 1.226 & 1.246 & 1.283 & 1.190 & 1.244 & 1.227 & 1.212 & 1.231 & 1.234 & 1.158 & 1.202 & 1.189 & 1.176 & 1.192 \\
\hline Aver. & 1.379 & 1.305 & 1.324 & 1.301 & 1.281 & & 1.092 & 1.233 & 1.201 & 1.177 & 1.175 & & 1.249 & 1.167 & 1.215 & 1.200 & 1.187 & \\
\hline \multicolumn{19}{|c|}{ Q10 values - water-logged soil } \\
\hline \multirow{2}{*}{ Treat. } & \multicolumn{6}{|c|}{ Silty clay soil } & \multicolumn{6}{|c|}{ Silty clay Loam soil } & \multicolumn{6}{|c|}{ Loamy sand soil } \\
\hline & 10 & 20 & 30 & 40 & 50 & Aver. & 10 & 20 & 30 & 40 & 50 & Aver. & 10 & 20 & 30 & 40 & 50 & Aver. \\
\hline Contr. & 1.267 & 1.174 & 1.222 & 1.214 & 1.200 & 1.215 & 1.252 & 1.170 & 1.218 & 1.203 & 1.190 & 1.206 & 1.280 & 1.188 & 1.241 & 1.274 & 1.210 & 1.238 \\
\hline $\mathrm{Cr}$ & 1.258 & 1.111 & 1.141 & 1.207 & 1.194 & 1.182 & 1.203 & 1.137 & 1.175 & 1.164 & 1.153 & 1.166 & 1.239 & 1.161 & 1.206 & 1.224 & 1.179 & 1.202 \\
\hline $\mathrm{Cd}$ & 1.163 & 1.167 & 1.214 & 1.132 & 1.123 & 1.160 & 1.283 & 1.189 & 1.243 & 1.227 & 1.212 & 1.231 & 1.272 & 1.182 & 1.234 & 1.192 & 1.204 & 1.217 \\
\hline $\mathrm{Pb}$ & 1.248 & 1.174 & 1.223 & 1.200 & 1.187 & 1.206 & 1.303 & 1.202 & 1.260 & 1.242 & 1.226 & 1.247 & 1.258 & 1.174 & 1.223 & 1.218 & 1.194 & 1.213 \\
\hline $\mathrm{Mn}$ & 1.259 & 1.132 & 1.168 & 1.208 & 1.194 & 1.192 & 1.276 & 1.185 & 1.237 & 1.221 & 1.207 & 1.225 & 1.263 & 1.177 & 1.227 & 1.207 & 1.198 & 1.214 \\
\hline $\mathrm{Fe}$ & 1.194 & 1.163 & 1.209 & 1.157 & 1.147 & 1.174 & 1.238 & 1.160 & 1.205 & 1.191 & 1.179 & 1.195 & 1.193 & 1.131 & 1.167 & 1.211 & 1.146 & 1.169 \\
\hline $\mathrm{Cu}$ & 1.243 & 1.198 & 1.254 & 1.195 & 1.182 & 1.214 & 1.240 & 1.162 & 1.207 & 1.193 & 1.180 & 1.196 & 1.270 & 1.181 & 1.232 & 1.156 & 1.202 & 1.208 \\
\hline $\mathrm{Zn}$ & 1.296 & 1.169 & 1.217 & 1.237 & 1.221 & 1.228 & 1.305 & 1.204 & 1.262 & 1.244 & 1.228 & 1.248 & 1.202 & 1.137 & 1.175 & 1.216 & 1.153 & 1.177 \\
\hline $\mathrm{Ni}$ & 1.252 & 1.179 & 1.230 & 1.202 & 1.189 & 1.210 & 1.244 & 1.164 & 1.211 & 1.196 & 1.184 & 1.200 & 1.319 & 1.212 & 1.241 & 1.163 & 1.238 & 1.235 \\
\hline Aver. & 1.242 & 1.163 & 1.209 & 1.195 & 1.182 & & 1.260 & 1.175 & 1.224 & 1.209 & 1.195 & & 1.255 & 1.171 & 1.216 & 1.207 & 1.191 & \\
\hline
\end{tabular}




\section{Discussion}

The results in fig (1) demonstrated that increasing the incubation temperature from 10 to $50^{\circ} \mathrm{C}$ increased the urease enzyme activity, however further increasing of temperature reduced the urease activity at all treatments. These results are in accorde with the results of Kizilkaya \& Ekberli (2008) which showed that the highest activity of urease enzyme obtained at a temperature between 40 and 50 ${ }^{\circ} \mathrm{C}$. Meng et al. (2006) has attributed the reduced activity of enzymes in the soil at high temperatures to high energy reactive molecules absorption leading to a change in the enzyme triple structure, it's nature and losing part of its effectiveness. Data of figure 1 also indicated that urease activity in soil treated with different heavy metals incubated under field capacity level were higher than those incubated under water logged moisture levels. This results is similar to that reported by Pulford \& Tabatabai (1988); Al-Jabri (2010) and Ou et al. (2019) who reported that urease activity decreased with increasing soil moisture content from field capacity to soil waterlogging limits. Burke et al. (2011) stated that soil water saturation reduces gas exchange between soil and the periphery that reduces soil aeration, and induced anaerobic conditions which negatively affect biological activity and consequently a significant decrease in enzymes activity. The organic substances, as ethanol, ethylene short-chain fatty acid ...etc accumulated under anaerobic condition may have adverse effect on the activity of soil enzyme (Setter et al., 2009).

The results of fig. (1) showed difference in urease activity in different soils being highest for silty clay soil and lowest for loamy sand soil. These findings are consistent with the findings of Busto \& Mateos (2000), Tawil
(2016) and Al-Ansari et al. (2019) which showed higher urease activity in silty clay loam soil than in loamy sand soils. The decrease in the activity of enzyme urease enzyme in loamy sand soil may be due to the low proportion of organic matter and clay content, which exposes the enzyme to the direct impact of thermal changes which will change the nature of the enzymatic protein and causes loss of activity, and the lack of organic matter leads to a lack of energy sources for the organisms and consequently a decrease in the number and activity of the livings producing the enzyme (Al-Ansari, 2000; Al-Jabri, 2010).

The results in figure1 showed negative effect of heavy metals on urease activity at all temperatures at both moisture levels as compared to control treatment. These results are consistent with Zaher et al. (2010) and Al Harkani (2018) who showed that decrease in urease activity of the soil treated with some heavy metals due to the effect of these elements on the activity of microorganism. Ofoegbu et al. (2013) reported that high concentration of heavy metals in soil reduce the number of soil microorganisms which is reflected on enzyme activity in soil.

Wyszkowska et al. (2006) showed that soil contamination with heavy metals plays a negative role in reducing the activity of microorganisms enzymes produced outside the cell. Dick (1997) indicated that heavy metals inhibit urease enzyme by binding it to complexes with the controlled substance, active groups in the enzyme or its effect on the enzyme complex- the controlled substance.

The results of the study in table (4) indicated significant differences in Ea values among different soils at both moisture levels. 
Low values of $\mathrm{Ea}$ are an indicator of the catalytic efficiency of the enzyme in converting the substrate into a product. The reaction is more rapid because of the role of the enzyme which reduces the activation energy needed by the reaction and the rise in Ea values needs more energy to activate the enzymes bound within the enzyme- controlled substance and enzyme release.

The results of table (5) presented that the Q10 values of urease enzymes differed according to heavy metals and soil used at both moisture levels. Significant difference in Q10 values were also noticed between soils incubated under field capacity level or waterlogged condition. Zaffren \& Hall (1973) reported that enzymatic reactions are sensitive to temperature change compared to chemical reactions, thus the values of $\mathrm{Q}_{10}$ for the enzymatic reaction are less than 2 while their value is greater than 2 in chemical reactions. Zhang et al. (2010) showed that values of activation energy (Ea) and temperature coefficient $\left(\mathrm{Q}_{10}\right)$ did not differ significantly when used four soils of different characteristics.

\section{Conclusions:}

The highest activity of urease enzyme was at a temperature $40-50^{\circ} \mathrm{C}$ and that its activity has varied with different heavy metals and different moisture levels. Effect of heavy metals on urease activity and thermodynamic parameter differ according to the temperature of incubation and the moisture level.

\section{Acknowledgments:}

The authors would like to extent their appreciation to department of soil science and water resources, College of Agriculture, University of Basrah for their financial support and provided places to this work accomplished.

\section{References:}

Al-Tawil, L.S.J. (2016). The effect of fertilizers in Amidohydrolases enzymes in sunflower (Helianthus annuus) Rhizoshper. Qadisiyah J. Sci. Biol., 6(2): 165-173. (In Arabic).

Al-Ansari, A.S. (2000). Characteristics of enzymes in recently reclaimed land Urease activity and kinetics parameters. Basrah J. Sci. Biol., 18: 111-122.

Al-Ansari, A.S.; Abdulkareem, M.A. \& Kadhum, S.J. (2019). Activity and thermodynamic parameters of urease in soil amended with organic residues. Iraqi J. Agric. Sci., 50(3): http://jcoagri.uobaghdad.edu.iq/index.php/i ntro/article/view/695.

Al-Jaberi, M.M. (2010). Amidohydrolases activity, kinetic and thermodynamic parameters in some marsh and southern Iraqi soils. Ph. D. Thesis. Coll. Agric., Univ. Basrah: 221pp. (In Arabic).

Al-Harakani, H.T.H. (2018). Soil bioreclamation treated with some heavy metals using locally isolated fungi and its effect on biological and enzymatic activity. M. Sc. Thesis, Coll. Agriculture, Univ. Basrah: 151pp. (In Arabic).

Busto, M.D. \& Perez-Mateos M. (2000). Characterization of B-D-glacosidase extracted from soil fractions. Eur. J. Soil Sci., 51: 193-200.

Burke, D.J.; Weintraub, M.N.; Hewins, C.R. \& Kalisz, S. (2011). Relationship between soil enzyme activities, nutrient cycling and soil fungal communities in a northern hardwood forest. Soil Biol. Biochem., 43: 795-803.

Ciarkowska K, \& Gambus’ F. (2004). Activity of dehydrogenase in heavy metal 
contaminated soils in the area of Olkusz Zesz. Probl. Post. Nauk. Rol., 501: 79-87.

Ciarkowska, K.; Sołek-Podwika, K. \& Wieczorek, J. (2014). Enzyme activity as an indicator of soil rehabilitation processes at a zinc and lead ore mining and processing area. J Environ Manage. 132: 250-256.

Cordero, I.; Snell, H. \& Richard, D.B. (2019). High throughput method for measuring urease activity in soil. Soil Biol. Biochem., 134: 72-77.

Dick, R.P. (1997). Soil Enzyme Activities as Integrative Indicators of Soil Health. In: Pankhurst, C. E., Doube, B. M., Gupta, V.V.S.R. (eds.) Biological Indicators of Soil Health, CABI Publishing. USA.

Dick, W.A. \& Tabatabai, M.A. (1999). Use of Immobilized Enzymes for Bioremediation. 315-338. In: ASSA (ed.). Bioremediation of Contaminated Soils. Agronomy Monograph 37, Madison: 820pp.

Follmer, C. (2008). Insights into the role and structure of plant ureases. Phytochemistry 69(1): 18-28.

Frankenberger, W.T. \& Tabatabai, M.A. (1980). Amidase activity in soils: II. Kinetic parameters. Soil. Sci. Soc. Am. J., 44: 532536.

Fraser, F.C.; Hallett, P.D.; Wookey, P.A.; Hartley, I.P. \& Hopkins, D.W. (2013). How do enzymes catalyzing soil nitrogen transformations respond to changing temperatures. Biol. Fertil. Soils, 49: 99103.

Gu, C.; Zhang, S.; Han, P.; Hu, X.; Xie, L.; Li, Y.; Brooks, M.; Liao, X. \& Qin, L. (2019). Soil enzyme activity in soils subjected to flooding and the effect on nitrogen and phosphorus uptake by oilseed rape. Front. Plant Sci., 10: 368. doi: 10.3389/fpls.2019.00368.

Hang X.; Li, F.; Liu, T.; Xu, C.; Duan, D.; Peng, C.; Zhu, S. \& Shi, J. (2013). The variations in the soil enzyme activity, protein expression, microbial biomass and community structure of soil contaminated by heavy metals. Int. Scholarly Res. Notices, 2013: 803150.. http://dx.doi.org/10.1155/2013/803150

Henry, H.A.L. (2012). Soil extracellular enzyme dynamics in a changing climate. Soil Biol. Biochem., 47: 53-59.

Kabata-Pendias, A. \& Pendias, H. (2001). Trace Elements in Soil and Plant. 3rd C.R.C. Press: 413pp.

Kizilkaya, R. \& Ekberli, I. (2008). Determination of the effects of hazelnut husk and tea waste treatments on urease enzyme activity and its kinetics in soil. Turk. J. Agric., 32: 299-310.

Krajewska, B. (2009). Urease1, functional, catalytic and kinetic properties: Areview. J. Mol. Catal. B. Enzym., 59: 9-21.

Kumari, J.A. \& Rao, P.C. (2017). Effect of temperature on soil enzymes urese activityproductivity. College of Agriculture, Rajendra Nagar, Hyderabad, In., 5(4): 6572 .

Maroney, M.J. \& Ciurli, S. (2013). Nonredox nickel enzymes. Chem. Rev., 114(8): 42064228.

Machuca, A.; Cuba-Díaz, M. \& Córdova, C. (2015). Enzymes in the rhizosphere of plants growing in the vicinity of the polish Arctowski antarctic station. J. Soil Sci. Plant Nutr., 15: 833-838.

Meng, F.X.; Ou, W.; Li Q.; Jiang, Y. \& Wen, D.Z. (2006). Vertical distribution and seasonal fluctuation of nematode tropic 
groups as affected by land use. Pedosphere, 15: 204-215.

Meng, X.; Yingwei A.; Ruirui L. \& Wenjuan Z. (2018). Effects of heavy metal pollution on enzyme activities in railway cut slope soils. 197 Page 2 of 12. Environ. Monit. Assess. 190: 197.

Ofoegbu, C.J.; Akubugwo, E.I.; Dike, C.C. Maduka, H.C.C.; Ugwu, C.E. \& Obasi, N.A. (2013). Effects of Heavy Metals on Soil Enzymatic Activities in the Ishiagu Mining Area of Ebonyi State-Nigeria. IOSR J. Environ. Sci. Toxicol. Food Technol., 5(6): 66-71.

Oliveira, A., \& Pampulha, M.E. (2006). Effects of long-term heavy metal contamination on soil microbial characteristics. J. Biosci. Bioeng., 102(3): 157-161.

Ou, Y.; Alain, N.; Rousseau, L.W.; Baixing, Y.; Thiago, G. \& Hui, Z. (2019). Identification of the alteration of riparian wetland on soil properties, enzyme activities and microbial communities following extreme flooding. Geoderma, 337: 825-833.

Pulford, I.D. \& Tabatabai M.A. (1988). Effect of waterlogging on enzyme activities in soils. Soil. Boil. Biochem., 20: 215-219.

Page, A.L.; Miller, R.H. \& Keeney, D.R. (1982). Methods of soil analysis. Part 2. $2^{\text {nd }}$. Ed. ASA. Inc. Madison, Wisconsin: 1158pp.

Setter, T.L.; Waters, I.; Sharma, S.K.; Singh, K.N.; Kulshreshtha, N. \& Yaduvanshi, N. P.S. (2009). Review of wheat improvement for waterlogging tolerance in Australia and India: the importance of anaerobiosis and element toxicities associated with different soils. Ann. Bot., 103: 221-235.
Tabatabai, M.A. (1994). Soil Enzymes. 775833. In: Bottomley, P.S.; Angle, J.R. \& Weaver, R.W. (Eds.). Methods of Soil Analysis. Part 2: Microbiological and Biochemical Properties. Soil Sci. Soc. Am., Madison, WI: 1121pp.

Tabatabi, M.A. \& Bremner, J.M. (1972). Assay of urease activity in soils. Soil. Biol. Biochem., 4: 479-487.

Wyszkowska, J.; Zaborowska, A. \& Kucharski, J. (2006). Activity of enzymes in zinc contaminated soil. EJPAU Environ. Develop., 9(1): 1-9.

Yang, Z.; Liu, S.; Zheng, D. \& Feng, S. (2006). Effects of cadmium, zinc and lead on soil enzyme activities. J. Environ. Sci. 18(6): 1135-1141.

Zaher, A.T.; Hadhili, K.H. \& Fakhir, S.J. (2010). Effect of some heavy metals on the effectiveness of microorganisms and urease enzyme activity in the soil. Basrah J. Agric. Sci.,, 23(2): 214-225. (In Arabic).

Zafren, E. \& Hall, P.L. (1973). The Study of Enzyme Mechanisms. John Wiley and Sons. Inc. New York: 284pp.

Zhang, F.P.; Li, C.F.; Tong, L.G.; Yue, L.X. \& Li, P. (2010). Response of microbial characteristics to heavy metal pollution of mining soils in central Tibet, China. Appl. Soil Ecol., 45: 144-151.

Zhang, N.; Pan, R.R.; Zhou, Z.H.; Liu, Y.; Jiang, J. \& Tian, Q. (2016). Effects of full wettish cultivation and waterlogging cultivation on soil nutrient content and enzyme activities. Acta Agric. Jiangxi, 28: 28-31. 